\title{
Selective Michael-type addition of a D-glucuronic acid derivative in the synthesis of model substances for uronic acid containing polysaccharides
}

\author{
K. Bergman, J. Hilborn, T. Bowden* \\ Department of Materials Chemistry, Division of Polymer Chemistry, Uppsala University, Box 538, \\ SE-751 21 Uppsala, Sweden
}

Received 8 May 2008; accepted in revised form 28 June 2008

\begin{abstract}
A flexible protocol for the preparation of model substances for uronic acid containing polysaccharides is presented. We have synthesized a D-glucuronic acid derivative which is designed so that it easily can be conjugated with different structures and architectures by selective Michael-type addition. By successful coupling of the glucuronic acid derivative to polyethylene glycol with high degree of conversion, products were obtained that were easily characterized and which resembled polysaccharides in terms of solubility and purification methods that could be employed. The model substance can potentially be used to facilitate optimization of low-degree modification reactions of high molecular weight D-glucuronic acid containing polysaccharides.
\end{abstract}

Keywords: polymer gels, polysaccharides, Michael-type addition, model substance, NMR

\section{Introduction}

Hydrogels are generally considered to be well suited as scaffolds for cell and tissue engineering applications due to their similarity to the natural extra cellular matrix [1-4]. Naturally occurring polysaccharides such as hyaluronic acid (hyaluronan) have received special attention for such purposes due to their biocompatibility and physiochemical properties [5]. Cross-linking of hyaluronic acid is a means to obtain an implantable hydrogel with controlled degradability and mechanical properties [6-8]. However, many cross-linking techniques employed today suffer drawbacks due to large degree modifications, which are necessary to compensate for the large extent of intramolecular reactions that occur when bifunctional cross-linkers are used [9]. In order to maintain the immunoneutrality and unique properties of native hyaluronic acid, it is suggested that the cross-linkable derivative should be modified to a low degree and synthesized under controlled conditions to avoid unwanted and unnecessary side reactions during modification and cross-linking. The degree of modification that can be performed without significantly altering properties of native hyaluronic acid depends on the type of modification and is a matter that deserves greater attention, although it is not a subject of further discussion in this report. Derivatives of uronic acid containing polysaccharides of high molecular weight which are modified to a low degree are difficult to characterize. To address this issue we have developed a synthetic protocol for the preparation of a model substance consisting of a novel D-glucuronic acid derivative that is conjugated with polyethylene glycol (PEG) (Figure 1). $\mathrm{D}$-glucuronic acid is found in the disaccharide

*Corresponding author, e-mail: bowden@mkem.uu.se

(c) BME-PT and GTE 


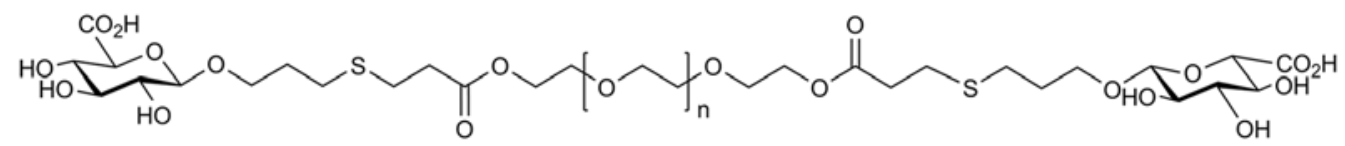

Figure 1. Structure of model substance for uronic acid containing polymers

repeat unit of hyaluronic acid and contains both a carboxylic acid and hydroxyl groups, which are the main targets for performing modifications. The model substance is an ideal candidate for optimizing modification reactions since the process can be followed by nuclear magnetic resonance (NMR), which otherwise is difficult due to the low degree of modification and high molecular weight of hyaluronic acid. Coupling the glucuronic acid derivative with PEG has added the feature to the model substance in the sense that it can be purified by techniques commonly used for polysaccharides, such as gel-filtration and dialysis. The glucuronic acid derivative is designed so that it can be easily combined with different structures and architectures by selective Michael-type addition, making it possible to obtain a substance easy to characterize yet large enough to handle purification wise.

\section{Experimental procedures}

\subsection{Materials and methods}

Polyethylene glycol with a molecular weight of $2000 \mathrm{~g} / \mathrm{mol}$ (PEG2000), purchased from VWR, and polyethylene glycol diacrylate with a molecular weight of $700 \mathrm{Da}$ (PEGDA700), from Aldrich, were used without further purification. Prior use, dichloromethane (VWR) was washed three times with de-ionized water, dried over $\mathrm{MgSO}_{4}$, filtered, refluxed over $\mathrm{CaH}_{2}$, distilled and stored over argon. Methanol (VWR) was refluxed over $\mathrm{CaH}_{2}$, distilled and stored over argon. All other chemicals were purchased of reagent grade or of higher purity from Aldrich, ACROS Organics, ABCR or VWR and were used without further purification. Column chromatography was performed on silica gel $60 \mathrm{G}$ (Merck) and monitored by thin layer chromatography (TLC) on fluorescent silica gel coated plates (Merck). ${ }^{1} \mathrm{H}$ NMR and ${ }^{13} \mathrm{C}$ NMR analyses were performed on a JEOL ECP $400 \mathrm{MHz}$ spectrometer with the solvent signal as an internal standard. FTIR spectra were recorded on a Perkin-Elmer Spectrum One spectrometer. Molecular mass and molecular mass distribution of the final products were obtained by matrix assisted laser desorption ionization time-of-flight mass spectrometry (MALDI-TOF MS) using a Bruker UltraFlex system with a SCOUT-MTP ion source (Bruker Daltonics, Bremen, Germany) operating in reflection mode and with 2,5-dihydroxybenzoic acid (DHB) as matrix. Samples were prepared in de-ionized water by mixing $5 \mu$ l of product $(1 \mathrm{mg} / \mathrm{ml})$ with $20 \mu \mathrm{l}$ of DHB $(10 \mathrm{mg} / \mathrm{ml})$. Melting point was determined by differential scanning calorimetry (DSCQ1000, TA Instruments).

\subsection{Synthesis of PEG diacrylate}

PEG2000 (5 g) was dissolved in $100 \mathrm{ml}$ toluene and dried azeotropically. Toluene was removed by rotary evaporation and the residue dried in vacuum. The dried polymer (1 g, $1 \mathrm{mmol}$ functional groups) was dissolved in $10 \mathrm{ml}$ freshly distilled dichloromethane under nitrogen while cooling in an icebath. To the solution was added $0.25 \mathrm{ml}$ acrylic anhydride $(2.2 \mathrm{mmol})$ and $0.3 \mathrm{ml}$ triethylamine $(2.2 \mathrm{mmol})$ and the reaction proceeded while stirring in the dark overnight at room temperature. The volume of the solution was reduced by rotary evaporation and the product (PEGDA2000) was collected by precipitation in cold diethyl ether, filtered and dried in vacuum. Yield: $89 \%$. ${ }^{1} \mathrm{H}$ NMR $\left(\right.$ DMSO- $\left._{6}\right): \delta(\mathrm{ppm})=3.51(\mathrm{~s}, \sim 234 \mathrm{H}, \mathrm{PEG}$ main chain), 3.64 (t, $4 \mathrm{H}, \mathrm{OCH}_{2} \mathrm{CH}_{2} \mathrm{OCOCH}=\mathrm{CH}_{2}$ ), 4.22 $\left(\mathrm{t}, 4 \mathrm{H}, \mathrm{OCH}_{2} \mathrm{CH}_{2} \mathrm{OCOCH}=\mathrm{CH}_{2}\right), 5.96(\mathrm{dd}, 2 \mathrm{H}, J$ $10.3 \mathrm{~Hz}$ and $\left.1.5 \mathrm{~Hz}, \mathrm{OCH}_{2} \mathrm{CH}_{2} \mathrm{OCOCH}=\mathrm{CH}_{2}\right)$, $6.20(\mathrm{dd}, 2 \mathrm{H}, \quad J \quad 17.2 \mathrm{~Hz}$ and $10.3 \mathrm{~Hz}$, $\left.\mathrm{OCH}_{2} \mathrm{CH}_{2} \mathrm{OCOCH}=\mathrm{CH}_{2}\right)$ and $6.34(\mathrm{dd}, 4 \mathrm{H}, J$ $17.2 \mathrm{~Hz}$ and $\left.1.46 \mathrm{~Hz}, \mathrm{OCH}_{2} \mathrm{CH}_{2} \mathrm{OCOCH}=\mathrm{CH}_{2}\right)$. FTIR: $v\left(\mathrm{~cm}^{-1}\right)=2883(\mathrm{C}-\mathrm{H}), 1724(\mathrm{C}=\mathrm{O}), 1467$ $\left(\mathrm{CH}_{2}\right), 1342,1279,1241,1194,1106,960$ and 842 (C-O-C).

\subsection{Synthesis of methyl (benzoyl 2,3,4-tri- $O$-benzoyl- $\alpha$-D-glucopyranoside) uronate, 1}

To a solution of powdered $\mathrm{NaOH}(20 \mathrm{mg}, 0.5 \mathrm{mmol})$ in $40 \mathrm{ml}$ freshly distilled methanol was added $4 \mathrm{~g}$ D-glucofurano-6,3-lactone $(22.7 \mathrm{mmol})$ followed 
by stirring in room temperature for 10 hours. The solution was concentrated by evaporation, the residue dissolved in $50 \mathrm{ml}$ pyridine and cooled to $0^{\circ} \mathrm{C}$. Benzoyl chloride $(16 \mathrm{ml}, 139 \mathrm{mmol})$ was added to the solution and stirred at room temperature overnight. The reaction mixture was diluted with $40 \mathrm{ml}$ ice-cold de-ionized water and $400 \mathrm{ml}$ dichloromethane, and then washed with saturated aqueous $\mathrm{NaHCO}_{3}$ and water. The organic phase was dried over $\mathrm{Na}_{2} \mathrm{SO}_{4}$ and concentrated by evaporation. The residue was purified by flash silica chromatography [heptane - ethyl acetate $(3: 2)$ ] to give 1 as a mixture of the $\alpha$ and $\beta$ anomers, $9.35 \mathrm{~g}$ $(66 \%) .{ }^{1} \mathrm{H} \mathrm{NMR}\left(\mathrm{CDCl}_{3}\right): \delta(\mathrm{ppm})=3.59(\mathrm{~s}, 3 \mathrm{H}$, $\mathrm{CO}_{2} \mathrm{CH}_{3} \beta$ ), 3.68 (s, $3 \mathrm{H}, \mathrm{CO}_{2} \mathrm{CH}_{3} \alpha$ ), $4.62(\mathrm{~d}, 1 \mathrm{H}, J$ $8.4 \mathrm{~Hz}, \mathrm{H}-5 \beta), 4.77$ (d, 1H, J 9.9 Hz, H-5 $\alpha$ ), 5.70 (dd, $1 \mathrm{H}, J 10.3 \mathrm{~Hz}$ and $3.7 \mathrm{~Hz}, \mathrm{H}-2 \alpha$ ), 5.77 (t, $1 \mathrm{H}$, $\mathrm{H}-4 \alpha), 5.83(\mathrm{~m}, 2 \mathrm{H}, \mathrm{H}-2$ and $\mathrm{H}-4 \beta), 6.02(\mathrm{t}, 1 \mathrm{H}$, H-3 $\beta$ ), 6.32 (m, 2H, H-1 $\beta$ and $\mathrm{H}-3 \alpha$ ), $6.92(\mathrm{~d}, 1 \mathrm{H}$, $J 3.7 \mathrm{~Hz}, \mathrm{H}-1 \alpha)$ and $7.28-8.15$ (m, 20H, Ph).

\subsection{Synthesis of methyl \\ (2,3,4-tri- $O$-benzoyl- $\alpha$-D-glucopyranosyl bromide) uronate, 2}

To $9 \mathrm{~g}$ of 1 (14.4 mmol) was added $36 \mathrm{ml} \mathrm{HBr}$ (33\% in acetic acid) followed by stirring in room temperature for 12 hours. The mixture was cooled to $0^{\circ} \mathrm{C}$, diluted with $180 \mathrm{ml}$ ice-cold dichloromethane and washed with saturated aqueous $\mathrm{NaHCO}_{3}$, de-ionized water and brine. The organic phase was dried over $\mathrm{MgSO}_{4}$, concentrated by evaporation and the residue dried in vacuum to give 2, $7.8 \mathrm{~g}(93 \%)$. ${ }^{1} \mathrm{H} \mathrm{NMR}\left(\mathrm{CDCl}_{3}\right): \delta(\mathrm{ppm})=3.69$ (s, 3H, $\left.\mathrm{CO}_{2} \mathrm{CH}_{3}\right), 4.85$ (d, $\left.1 \mathrm{H}, J 10.3 \mathrm{~Hz}, \mathrm{H}-5\right), 5.34$ $(\mathrm{dd}, 1 \mathrm{H}, J 9.9 \mathrm{~Hz}$ and $4.0 \mathrm{~Hz}, \mathrm{H}-2), 5.72(\mathrm{t}, 1 \mathrm{H}$, H-4), 6.27 (t, 1H, H-3), 6.85 (d, 1H, J 4.0 Hz, H-1) and 7.30-7.99 (m, 15H, Ph).

\subsection{Synthesis of Methyl (Allyl 2,3,4-Tri-O-benzoyl- $\beta$-D-glucopyranoside) uronate, 3}

Compound 2 ( $3.35 \mathrm{~g}, 5.7 \mathrm{mmol}$ ) was dissolved in $60 \mathrm{ml}$ freshly distilled dichloromethane together with activated $4 \AA$ molecular sieves under $\mathrm{N}_{2}$ in a two-armed round-bottomed flask equipped with a condenser. To the solution was added $2 \mathrm{ml}$ allyl alcohol (29.4 mmol) and $1.58 \mathrm{~g} \mathrm{Ag}_{2} \mathrm{CO}_{3}(5.7 \mathrm{mmol})$. After stirring at $30^{\circ} \mathrm{C}$ for 48 hours the solution was filtered and concentrated by evaporation. The residue was purified by flash silica chromatography [hexane - ethyl acetate (3:2)] to give $3,1.50 \mathrm{~g}$ $(47 \%) .{ }^{1} \mathrm{H}$ NMR $\left(\mathrm{CDCl}_{3}\right): \delta(\mathrm{ppm})=3.70(\mathrm{~s}, 3 \mathrm{H}$, $\left.\mathrm{CO}_{2} \mathrm{CH}_{3}\right), 4.17\left(\mathrm{~m}, 1 \mathrm{H}, \mathrm{OCH}_{2} \mathrm{CH}=\mathrm{CH}_{2}\right), 4.34(\mathrm{~d}$, $1 \mathrm{H}, J 9.5 \mathrm{~Hz}, \mathrm{H}-5), 4.42\left(\mathrm{~m}, 1 \mathrm{H}, \mathrm{OCH}_{2} \mathrm{CH}=\mathrm{CH}_{2}\right)$, $4.91(\mathrm{~d}, 1 \mathrm{H}, J 7.3 \mathrm{~Hz}, \mathrm{H}-1), 5.16$ and $5.26(\mathrm{~m}, 2 \mathrm{H}$, $\left.\mathrm{OCH}_{2} \mathrm{CH}=\mathrm{CH}_{2}\right), 5.56(\mathrm{dd}, 1 \mathrm{H}, J 9.2 \mathrm{~Hz}$ and $7.7 \mathrm{~Hz}$, $\mathrm{H}-2), \quad 5.69(\mathrm{t}, \quad 1 \mathrm{H}, \quad \mathrm{H}-4), \quad 5.79(\mathrm{~m}, \quad 1 \mathrm{H}$, $\left.\mathrm{OCH}_{2} \mathrm{CH}=\mathrm{CH}_{2}\right), 5.90(\mathrm{t}, 1 \mathrm{H}, \mathrm{H}-3)$ and $7.28-7.96$ $(\mathrm{m}, 15 \mathrm{H}, \mathrm{Ph}) .{ }^{13} \mathrm{C} \mathrm{NMR}\left(\mathrm{CDCl}_{3}\right): \delta(\mathrm{ppm})=53.0$, $70.2, \quad 70.3,71.6, \quad 72.1, \quad 73.0, \quad 99.7, \quad 118.2$, $128.4-128.5,129.9,133.2-133.5,165.1,165.3$, 165.7 and 167.5.

\subsection{Synthesis of methyl (3-thioacetoxypropyl 2,3,4-tri- $O$-benzoyl- $\beta$-D-glucopyranoside) uronate, 4}

To a solution of $41 \mathrm{mg}$ 2,2'-Azobis(2-methylpropionitrile) (AIBN, $0.25 \mathrm{mmol}$ ) in $8.5 \mathrm{ml}$ dioxane was added $560 \mathrm{mg}$ of $\mathbf{3}$ (1 mmol). The solution flask was flushed with argon gas and cooled on ice, and $1.1 \mathrm{ml}$ thioacetic acid (15.3 mmol) added. The mixture was subjected to a freeze-vacuum-thaw process three times, purged with argon gas and stirred at $75^{\circ} \mathrm{C}$ for 4 hours. The reaction was quenched by flushing with air, the solution concentrated by evaporation from toluene and the product purified by flash silica chromatography [hexane ethyl acetate (gradient, 95-67\% hexane)] to give $\mathbf{4}$, $390 \mathrm{mg}(61 \%) .{ }^{1} \mathrm{H} \mathrm{NMR}\left(\mathrm{CDCl}_{3}\right): \delta(\mathrm{ppm})=1.83$ $\left(\mathrm{m}, 2 \mathrm{H}, \mathrm{OCH}_{2} \mathrm{CH}_{2} \mathrm{CH}_{2} \mathrm{SCOCH}_{3}\right), 2.24(\mathrm{~s}, 3 \mathrm{H}$, $\left.\mathrm{SCOCH}_{3}\right), 2.81\left(\mathrm{~m}, 2 \mathrm{H}, \mathrm{OCH}_{2} \mathrm{CH}_{2} \mathrm{CH}_{2} \mathrm{SCOCH}_{3}\right)$, $3.59\left(\mathrm{~m}, 1 \mathrm{H}, \mathrm{OCH}_{2} \mathrm{CH}_{2} \mathrm{CH}_{2} \mathrm{SCOCH}_{3}\right), 3.69(\mathrm{~s}, 3 \mathrm{H}$, $\left.\mathrm{CO}_{2} \mathrm{CH}_{3}\right), 4.02\left(\mathrm{~m}, 1 \mathrm{H}, \mathrm{OCH}_{2} \mathrm{CH}_{2} \mathrm{CH}_{2} \mathrm{SCOCH}_{3}\right)$, 4.34 (d, 1H, J 9.5 Hz, H-5), 4.84 (d, 1H, J 7.3 Hz, $\mathrm{H}-1), 5.52(\mathrm{dd}, 1 \mathrm{H}, J 9.5 \mathrm{~Hz}$ and $7.3 \mathrm{~Hz}, \mathrm{H}-2), 5.67$ (t, 1H, H-4), $5.90(\mathrm{t}, 1 \mathrm{H}, \mathrm{H}-3)$ and 7.28-7.96 (m, $15 \mathrm{H}, \mathrm{Ph}) .{ }^{13} \mathrm{C} \mathrm{NMR}\left(\mathrm{CDCl}_{3}\right): \delta(\mathrm{ppm})=25.7,29.4$, 30.6, 53.0, 68.7, 70.3, 71.6, 72.1, 73.0, 101.2, 128.4-129.2, 129.9, 133.4-133.6, 165.1, 165.3, 165.7, 167.5 and 195.9.

\subsection{Synthesis of PEG diglucuronic acid, 5a and $5 b$}

To a sealed round-bottomed flask thoroughly purged with nitrogen gas containing $150 \mathrm{mg}$ of 4 $(0.24 \mathrm{mmol})$ was added a degassed methanol - 
deionized water mixture $(5: 1,9 \mathrm{ml})$. The mixture was heated to $55^{\circ} \mathrm{C}$ and stirred until dissolution before cooling in ice and adding $1.5 \mathrm{ml}$ degassed $3 \mathrm{M} \mathrm{NaOH}$. After stirring at room temperature for 6 hours the solution was transferred to Dowex $\mathrm{H}^{+}$ $50 \times 8-100$ sulfonic resin (Aldrich) in a sealed flask flushed with nitrogen gas and stirred at room temperature for 20 minutes. The solution was transferred to a sealed flask flushed with nitrogen gas, containing $50 \mathrm{mg}$ PEGDA700 (0.14 mmol functional groups). A degassed $0.5 \mathrm{M} \mathrm{NaHCO}_{3}$-solution was added until $\mathrm{pH} 9$ was reached and the flask was agitated at room temperature for 15 hours. Methanol was removed by evaporation and the residue purified by gel-filtration using a SephadexG25 PD-10 pre-packed column (Amersham Biosciences). The eluted solution was mixed with Dowex $\mathrm{H}^{+}$and lyophilized to give 5a as a yellow resin. Yield: $73 \mathrm{mg}$ (83\%). ${ }^{1} \mathrm{H}$ NMR $\left(\mathrm{D}_{2} \mathrm{O}\right)$ : $\delta(\mathrm{ppm})=1.87(\mathrm{~m}, 4 \mathrm{H}), 2.65,2.71$ and $2.80(\mathrm{t}, 4 \mathrm{H}$ each), $3.28(\mathrm{t}, 2 \mathrm{H}), 3.51(\mathrm{~m}, 4 \mathrm{H}), 3.61-3.72(\mathrm{~m}$, $\sim 60 \mathrm{H}), 3.75(\mathrm{t}, 4 \mathrm{H}), 3.94(\mathrm{~m}, 4 \mathrm{H}), 4.26(\mathrm{t}, 4 \mathrm{H})$ and $4.48(\mathrm{~d}, 2 \mathrm{H}, J 8.0 \mathrm{~Hz})$. Assignments of ${ }^{1} \mathrm{H}$ NMRpeaks are demonstrated in Figure 2. ${ }^{13} \mathrm{C}$ NMR $\left(\mathrm{D}_{2} \mathrm{O}\right): \delta(\mathrm{ppm})=26.3,27.7,28.9,34.3,64.2,68.6$, 69.2, 69.7, 71.5, 72.9, 74.8, 75.4, 102.5, 172.6 and 174.7. MS (MALDI-TOF): $M_{n}=1231, M_{w}=1243$ and $M_{w} / M_{n}=1.01$. Compound $\mathbf{5 b}$ was synthesized with PEGDA2000 according to the preparation of 5a and purified by dialysis (Spectra/Por 6 RC Dialysis membrane tubing MWCO 1000) followed by<smiles>C=CC(=O)OCCOC(C)(C)COC(C)(C)OCCOC(=O)C=C</smiles>

Figure 2. Synthesis of PEG diacrylate

mixing with Dowex $\mathrm{H}^{+}$and freeze-drying. Yield: $106 \mathrm{mg}(57 \%)$. ${ }^{1} \mathrm{H}$ NMR $\left(\mathrm{D}_{2} \mathrm{O}\right): \delta(\mathrm{ppm})=1.87$ $(\mathrm{m}, 4 \mathrm{H}), 2.64,2.70$ and $2.80(\mathrm{t}, 4 \mathrm{H}$ each), $3.27(\mathrm{t}$, $2 \mathrm{H}), 3.51(\mathrm{~m}, 4 \mathrm{H}), 3.60-3.72(\mathrm{~m}, \sim 246 \mathrm{H}), 3.75(\mathrm{~m}$, $4 \mathrm{H}), 3.93(\mathrm{~m}, 4 \mathrm{H}), 4.26(\mathrm{t}, 4 \mathrm{H})$ and $4.47(\mathrm{~d}, 2 \mathrm{H}, J$ $8.0 \mathrm{~Hz}) .{ }^{13} \mathrm{C}$ NMR $\left(\mathrm{D}_{2} \mathrm{O}\right): \delta(\mathrm{ppm})=26.3,27.6$, 29.0, 34.3, 64.2, 68.6, 69.2, 69.7, 71.5, 72.9, 74.8, 75.4, 102.5, 172.7 and 174.7. MS (MALDI-TOF): $M_{n}=2545, M_{w}=2565$ and $M_{w} / M_{n}=1.01 . T_{m}=$ $40-49^{\circ} \mathrm{C}$

\section{Results and discussion}

The model substance is versatile in the sense that the glucuronic acid derivative easily can be combined with appropriate macromolecules through a selective Michael-type addition that previously has been described by Lutolf et al. [10]. In this study PEG was chosen, which simplifies characterization with NMR spectroscopy due to the absence of functional groups on the main chain and brings properties to the model substance resembling hyaluronic acid in terms of solubility and purifica-
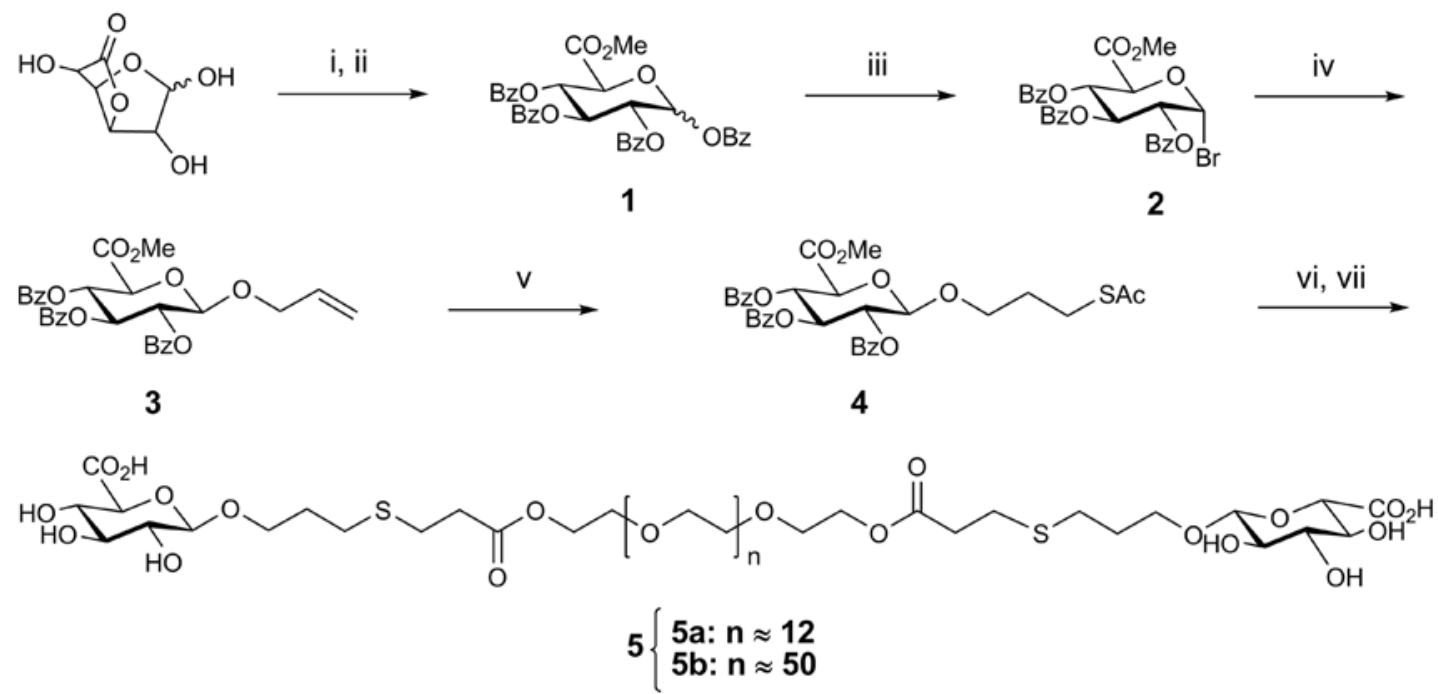

Figure 3. Synthesis of PEG diglucuronic acid. Reagents and conditions: : i) $\mathrm{MeOH}, \mathrm{NaOH}, 10$ h; ii) Pyridine, $\mathrm{PhCOCl}$, overnight; iii) $\mathrm{HBr} 33 \%$ in $\mathrm{AcOH}$, room temperaure, $12 \mathrm{~h}$; iv) Allyl alcohol, $\mathrm{Ag}_{2} \mathrm{CO}_{3} 30^{\circ} \mathrm{C} 48 \mathrm{~h}$; v) $\mathrm{AcSH}$, AIBN $75^{\circ} \mathrm{C} 4 \mathrm{~h}$; vi) $\mathrm{NaOH}(3 \mathrm{M}), 6 \mathrm{~h}$, then Dowex $\mathrm{H}^{+}$; vii) PEGDA, $\mathrm{NaHCO}_{3}(0.5 \mathrm{M}) \mathrm{pH} 9,15 \mathrm{~h}$, then Dowex $\mathrm{H}^{+}$ 
tion methods that can be utilized. PEG diacrylate was successfully synthesized from PEG with a molecular weight of $2000 \mathrm{~g} / \mathrm{mol}$ according to Figure 2, whereas PEG diacrylate with a molecular weight of $700 \mathrm{~g} / \mathrm{mol}$ was found commercially available.
The strategy employed for synthesizing the model substance (Figure 3) involved five steps beginning with the preparation of a benzoyl protected glucopyranoside uronate as a mixture of the $\alpha$ and $\beta$ anomers (1), which further was converted to an $\alpha$ bromide (2) using methods previously published by
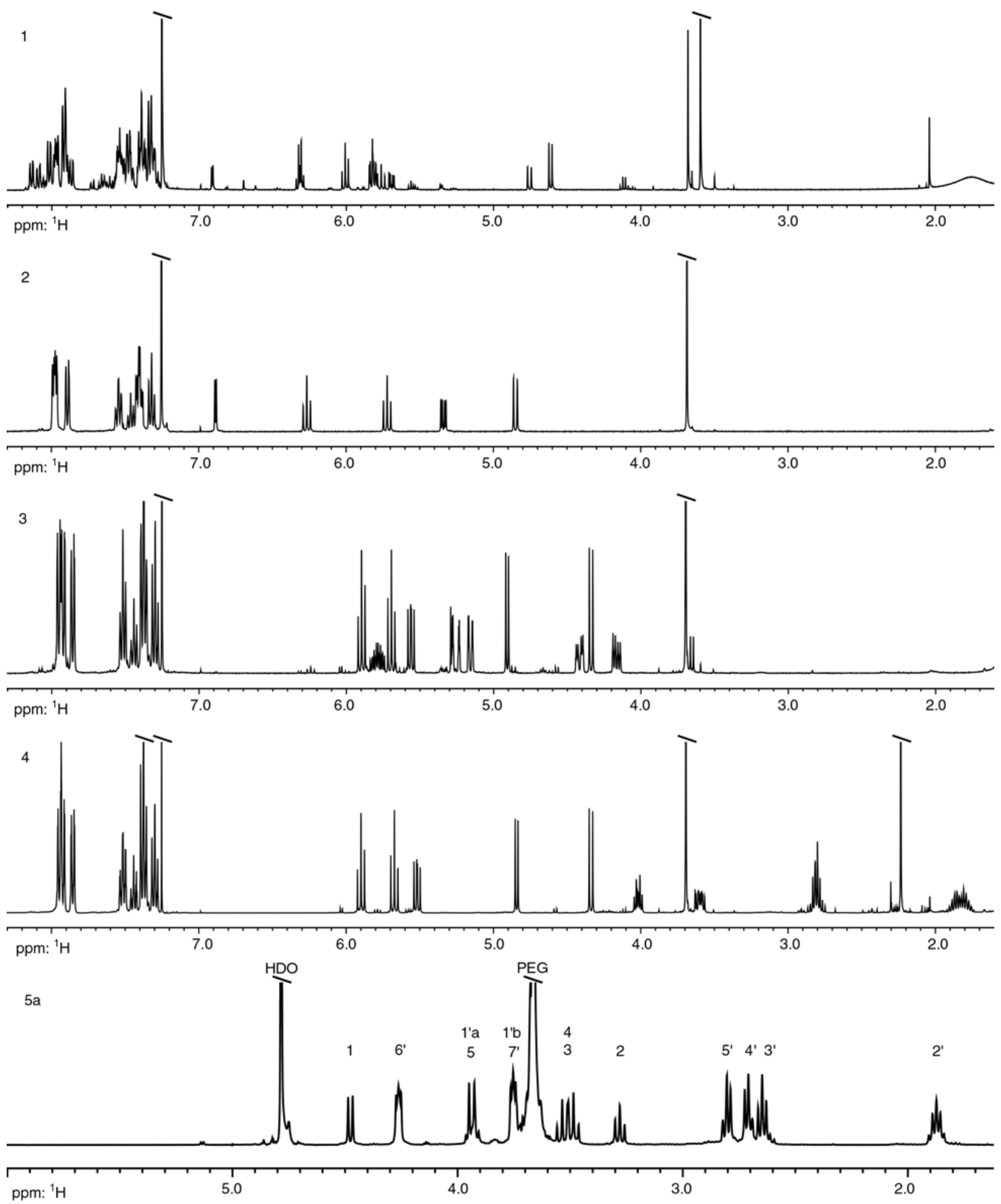

Figure 4. ${ }^{1} \mathrm{H}$ NMR spectra of compounds $\mathbf{1 - 5 a}$ recorded at $400 \mathrm{MHz}$. Peaks for substance 5a are assigned labels according to IUPAC nomenclature 
Coutant and Jacquinet [11]. In the following step allyl alcohol was introduced to the bromide, which proved most successful by the classical KoenigsKnorr glycosylation in the presence of silver carbonate [12]. Radical elongation of $\mathbf{3}$ with thioacetic acid afforded 4, which was further converted to a thiol and simultaneously deprotected by treatment of sodium hydroxide under nitrogen while cooling. Deprotection performed without cooling, under otherwise same conditions, resulted in the formation of $\beta$-elimination product. An excess of the thio-glycoside was coupled with PEGDA under nitrogen without prior purification in order to avoid disulfide formation, and resulted in high yields of product (5a and $\mathbf{5 b}$ ). Although disulfides are readily formed in the presence of oxygen, thiols have shown to be ideal for the Michael-type addition to unsaturated esters [10]. The products were appropriately purified to remove salts and excess starting material.

Characterization of the final products $(\mathbf{5} \mathbf{a}$ and $\mathbf{5 b})$ with NMR spectroscopy confirmed a high purity and a full conversion, as indicated by the complete absence of signals from acrylate protons and by the ratio of integrated signals originating from the anomeric protons on the glucuronic acid moieties $(\delta=4.48 \mathrm{ppm})$ and protons on the main chain of PEG $(\delta=3.65 \mathrm{ppm})$. A typical ${ }^{1} \mathrm{H}$ NMR spectrum of the model substance (5a) is demonstrated in Figure 4, along with spectra for compounds 1-4. Performing COSY NMR experiments enabled assignment of overlapping signals. MALDI-TOF MS was used to determine molecular mass and molecular mass distributions of the conjugates, which also confirmed a high conversion degree. A typical MALDI-TOF mass spectrum of the model substance with uniformly distributed $44 \mathrm{~g} / \mathrm{mol}$ spaced

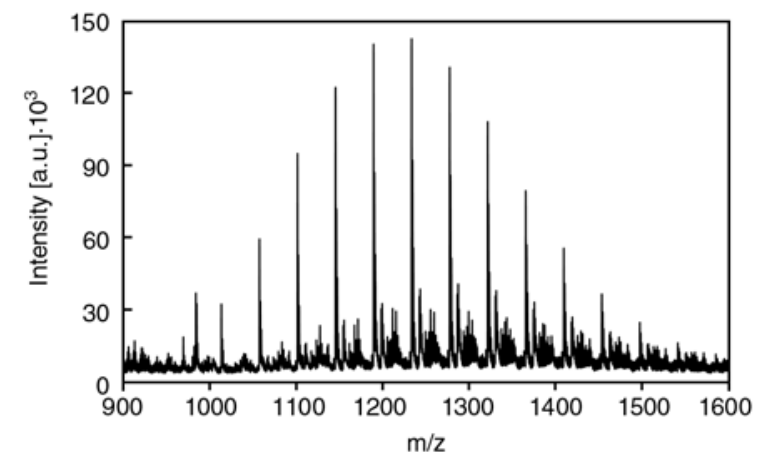

Figure 5. MALDI-TOF mass spectrum of PEG diglucuronic acid (5a) lines attributed to the PEG repeat unit is provided in Figure 5.

On one hand, the higher molecular weight conjugate $(\mathbf{5 b})$ has the advantage of being solid at room temperature, adding the possibility to purify by precipitation. On the other hand a model substance with lower molecular weight (e.g. 5a) is preferred characterization wise. In addition to use the glucuronic acid derivative as model substances for optimizing modification reactions, it may be used for the preparation of glycoconjugates that are of interest in the study of the biological role of carbohydrates. Although the described model substance currently is used for the development of new crosslinking chemistry for hyaluronic acid, it may also be applied for other D-glucuronic acid containing polysaccharides such as chondroitin sulfate, heparin and heparan sulfate.

\section{Conclusions}

A protocol for the preparation of a model substance for uronic acid containing polysaccharides has been developed. The model substance consists of a D-glucuronic acid - PEG conjugate which was synthesized in five steps. Selective Michael-type addition enabled coupling of the thiolated D-glucuronic acid derivative with full conversion to PEG-diacrylate of two different molecular weights. By conjugating the glucuronic acid derivative with different structures and architectures it is possible to obtain model substances which resemble polysaccharides while at the same time are easier to characterize. We believe that the protocol is a flexible route to the preparation of model substances which can be used in the optimization of modification reaction for high molecular weight polysaccharides.

\section{Acknowledgements}

The Swedish Research Council (VR) is acknowledged for the financial support of this work.

\section{References}

[1] Lee K. Y., Mooney D. J.: Hydrogels for tissue engineering. Chemical Reviews, 101, 1869-1879 (2001).

[2] Hoffman A. S.: Hydrogels for biomedical applications. Advanced Drug Delivery Reviews, 54, 3-12 (2002). 
[3] Hubbell J. A.: Synthetic biodegradable polymers for tissue engineering and drug delivery. Current Opinions in Solid State and Materials Science, 3, 246-251 (1998).

[4] Nitschke M., Götze T., Gramm S., Werner C.: Detachment of human endothelial cell sheets from thermoresponsive poly(NiPAAm-co-DEGMA) carriers. Express Polymer Letters, 1, 660-666 (2007).

[5] Atala A., Lanza R. P.: Methods of tissue engineering. Academic Press, San Diego (2002).

[6] Campoccia D., Doherty P., Radice M., Brun P., Abatangelo G., Williams D. F.: Semisynthetic resorbable materials from hyaluronan esterfication. Biomaterials, 19, 2101-2127 (1998).

[7] Shu X. Z., Liu Y., Luo Y., Roberts M. C., Prestwich G. D.: Disulfide cross-linked hyaluronan hydrogels. Biomacromolecules, 3, 1304-1311 (2002).

[8] Segura T., Anderson B. C., Chung P. H., Webber R. C., Shull K. R., Shea L. D.: Crosslinked hyaluronic acid hydrogels: A strategy to functionalize and pattern. Biomaterials, 26, 359-371 (2005).
[9] Ossipov D. A., Hilborn J.: Poly(vinyl alcohol)-based hydrogels formed by 'click chemistry'. Macromolecules, 39, 1709-1718 (2006).

[10] Lutolf M. P., Tirelli N., Cerritelli S., Cavalli L., Hubbell J. A.: Systematic modulation of Michael-type reactivity of thiols through the use of charged amino acids. Bioconjugate Chemistry, 12, 1051-1056 (2001).

[11] Coutant C., Jacquinet J-C.: 2-deoxy-2-trichloroacetamido-D-glucopyranose derivatives in oligosaccharide synthesis: From hyaluronic acid to chondroitin 4-sulfate trisaccharides. Journal of the Chemical Society: Perkin Transactions 1, 12, 1573-1581 (1995).

[12] Koenigs W., Knorr E.: Über einige Derivate des Traubenzuckers und der Galactose. Berichte der Deutsche Chemische Gesellschaft, 34, 957-981 (1901). 